\title{
Letter regarding the Paper by Pearce et al. Entitled '2013 ETA Guideline: Management of Subclinical Hypothyroidism'
}

\author{
Simon P. Mooijaart ${ }^{\mathrm{a}, \mathrm{b}}$ on behalf of the IEMO 80-Plus Thyroid Trial Collaboration \\ a Institute for Evidence-Based Medicine in Old Age/IEMO, and ${ }^{\mathrm{b}}$ Department of Gerontology and Geriatrics, \\ Leiden University Medical Center, Leiden, The Netherlands
}

Dear Editor,

In this letter we would like to emphasize a specific part of the new ETA guideline which was explained in the paper by Pearce et al. [1], more specifically the part on thyroid hormone supplementation in the oldest old.

In the guideline it is recommended that thyroid hormone supplementation 'should generally be stopped' in the oldest old with a TSH above the normal range but $\leq 10$ $\mathrm{mU} / \mathrm{l}$, but the clinical evidence for this statement is graded as level 3 [i.e. low quality (case series, case reports, expert opinion)]. For this reason, it is also stated that appropriately powered randomized controlled trials of L-thyroxine in patients with subclinical hypothyroidism, examining hard cardiovascular endpoints in various classes of age, are clearly warranted [1]. This recommendation is in line with the latest Cochrane review on this subject [2].

The conservative treatment recommendation in those over 80 years with a $\mathrm{TSH}$ above the normal range but $\leq 10 \mathrm{mU} / \mathrm{l}$ is based on findings from the Leiden 85Plus Study [3]. In this observational followup study comprising a population-based sample of 562 persons aged 85 years, those with subclinical hypothyroidism lived longer than those with normal thyroid function. However, the observational design of this study did not allow for definite conclusions about the effect of treatment. In the oldest old, for example, higher blood pressure [4] and high cholesterol [5] have been associated with lower mortality, whereas randomized trials nevertheless have shown that treatment with antihypertensives [6] and statins [7], respectively, remains beneficial up to the highest age groups. It is for this reason that the ETA guideline also states that since observational studies are subject to several limitations, clinical decisions based only on these data should be made with great caution. Furthermore, in a later meta-analysis including individual patient data of over 50,000 participants, no beneficial effect of subclinical hypothyroidism was seen in the total subgroup of patients $\geq 80$ years [8]. Another argument against treatment would be the risk of overtreatment [9].

An argument in favor of treatment would be that in older patients, thyroid function testing is often requested because of symptoms concerning mood, fatigue, or cognition. There is no evidence that the effectiveness of thyroid hormone supplementation on complaints is different in older patients compared to younger patients, whereas in younger patients with TSH above the normal range but $\leq 10$ $\mathrm{mU} / \mathrm{l}$, treatment is recommended in the presence of symptoms.

Although a conservative approach to the treatment of older people is defendable, so is an approach to start treatment in case of complaints, which are likely to be present. This clinical equipoise has spurred us to initiate a much needed and clearly warranted [see Pearce et al. 1] randomized controlled trial on supplementation of subclinical hypothyroidism in those over 80 years of age (IEMO 80-Plus Thyroid Trial, NTR3851, www.trialregister.nl), with an independent data safety monitoring board to monitor overtreatment and negative side effects. In a nationwide initiative in the Netherlands, we are currently recruiting 450 older adults with persistent subclinical hypothyroidism. The primary endpoints of the trial include a combined cardiovascular end-

\section{KARGER}

E-Mail karger@karger.com www.karger.com/etj
(C) 2014 European Thyroid Association

Published by S. Karger AG, Basel

2235-0640/14/0032-0141\$39.50/0
Mr. Simon P. Mooijaart

Department of Gerontology and Geriatrics

Leiden University Medical Center, PO Box 9600

NL-2300 RC Leiden (The Netherlands)

E-Mail s.p.mooijaart@lumc.nl 
point and thyroid-specific quality of life. Secondary endpoints include overall mortality, quality of life, functional capacity, and cognitive function. Analyses of this trial will include a preplanned pooled analysis of all endpoints in all 80-plus participants together with TRUST (Thyroid Hormone Replacement for Untreated Older Adults with Subclinical Hypothyroidism Trial, ClinicalTrials.gov NCT01660126).

Clinical recommendations in the absence of solid evidence should be interpreted with caution. We would therefore like to emphasize the lack of evidence in this particular age group to readers of the guidelines, and to advise them to consider the lack of evidence when applying the recommendations to their individual older patients. It is important that the need for randomized controlled trials is underlined by this ETA guideline, and that despite arguments for a conservative treatment approach of subclinical hypothyroidism in those over 80 years of age, doctors see this as an encouragement to include these patients in relevant trials on the matter.

\section{Funding}

The IEMO 80-Plus Thyroid Trial is funded by an unrestricted grant from the Dutch Ministry of Health, Welfare and Sports, and is supported by ZonMw (project No. 627001001).

\section{Disclosure Statement}

The author declares that no financial or other conflict of interest exists in relation to the content of the article.

\section{References}

1 Pearce SHS, Brabant G, Duntas LH, et al: 2013 ETA guideline: management of subclinical hypothyroidism. Eur Thyroid J 2013;2:215228.

$\checkmark 2$ Villar HC, Saconato H, Valente O, Atallah AN: Thyroid hormone replacement for subclinical hypothyroidism. Cochrane Database Syst Rev 2007;3:CD003419.

- 3 Gussekloo J, van Exel E, de Craen AJ, et al: Thyroid status, disability and cognitive function, and survival in old age. JAMA 2004;292: 2591-2599.
4 van Bemmel T, Gussekloo J, Westendorp RG, Blauw GJ: In a population-based prospective study, no association between high blood pressure and mortality after age 85 years. J Hypertens 2006;24:287-292.

5 Weverling-Rijnsburger AW, Blauw GJ, Lagaay AM, Knook DL, Meinders AE, Westendorp RG: Total cholesterol and risk of mortality in the oldest old. Lancet 1997;350: 1119-1123.

-6 Beckett NS, Peters R, Fletcher AE, et al: Treatment of hypertension in patients 80 years of age or older. N Engl J Med 2008;358:18871898.
Shepherd J, Blauw GJ, Murphy MB, et al: Pravastatin in elderly individuals at risk of vascular disease (PROSPER): a randomised controlled trial. Lancet 2002;360:1623-1630.

8 Rodondi N, den Elzen WPJ, Bauer DC, et al: Subclinical hypothyroidism and the risk of coronary heart disease and mortality. JAMA 2010;304:1365-1374.

-9 Parle JV, Franklyn JA, Cross KW, Jones SR, Sheppard MC: Thyroxine prescription in the community: serum thyroid stimulating hormone level assays as an indicator of undertreatment or overtreatment. Br J Gen Pract 1993;43:107-109. 